the specified product geometry and, as a consequence for the user, the necessity of making additional efforts during the operation or maintenance of the product.

Minor consequences. As a rule, they occur in a situation where welded products, are part of technical systems and the loss of functionality of the weld due to porosity does not lead to loss of functionality of the system. Such welds are usually not load-bearing.

The application of the proposed classification of consequences will simplify the quantitative analysis of the risks of non-compliance with the requirements for the porosity of welds.

\title{
References:
}

1. Haievskyi V. Reducing risks of welding porosity. International Scientific Conference Scientific Development of New Eastern Europe: Conference Proceedings (Riga, November 15th, 2019.). Riga: Baltija Publishing, 2019. Р. 54-55.

2. Гаевский В. О., Прохоренко В. М., Чвертко Е. П., Ахматбеков М. Т. Ограничение рисков невыполнения требований к пористости сварных швов. Труды Университета. Карагандинский государственный технический университет. 2016. № 1. С. 45-48.

3. Гаєвський В. О., Гаєвський О. А., Зворикін К. О. Визначення параметрів Вейбулівського розподілу діаметру пор. Технологические системы. 2019. № 1. С. 75-79.

DOI https://doi.org/10.30525/978-9934-588-79-2-1.25

\section{МОНІТОРИНГ РЕЗУЛЬТАТІВ ПРОФЕСІЙНОЇ ПІДГОТОВКИ ЗВАРНИКІВ ПІД ЧАС НАВЧАННЯ ТА ПРИ ПІДГОТОВЦІ ДО КВАЛІФІКАЦІЙНОЇ АТЕСТАЦІї}

\author{
Дідківський Р. М. \\ аспірант,
}

кафедра смарт технологій з'єднань та інженерії поверхонь

Національного технічного університету Украӥни

«Київський політехнічний інститут імені Ігоря Сікорського»

Чвертко Є. П.

кандидат технічних наук, доцент,

Начіонального технічного університету Украӥни

«Киівський політехнічний інститут імені Ігоря Сікорського» 
Шевченко М. В.

кандидат технічних наук, дочент,

Національного технічного університету Украӥни

«Київський політехнічний інститут імені Ігоря Сікорського»

м. Київ, Украӥна

Ручне дугове зварювання плавким електродом і механізоване зварювання в середовищі захисних газів в даний час є найбільш розповсюдженими способами отримання нероз'ємних з'єднань при виготовленні широкої номенклатури металоконструкцій. При виконанні зварювання даними способами велику роль відіграє людський фактор. Тому основними аспектами забезпечення якості в зварювальному виробництві $\epsilon$ контроль за процесом зварювання у реальному часі, а також компетентність персоналу зварювального виробництва. Слід відмітити що, останнім часом на ринку праці постійно зростає потреба в кваліфікованих зварниках [1, с. 19-23].

Загалом підготовка зварників $є$ складним, витратним і тривалим процесом результатом якого $\epsilon$ формування та закріплення практичних навичок. До яких відносяться: переміщення робочого інструменту (електродотримач, пальник) уздовж заданої траєкторії з заданою швидкість, маніпуляції торцем зварювального електрода з заданою частотою та амплітудою, підтримання поздовжнього і поперечного кута нахилу робочого інструменту, вертикального переміщення електроду для підтримання оптимальної довжини дугового проміжку. Переважна більшість кандидатів на навчання мають різний рівень освіти та досвід роботи, наявність чинних атестацій і сертифікатів, тому тривалість навчальної програми може змінюватись в певних межах. Рівень освіти впливає на теоретичну підготовку кандидата та ступінь розуміння ним технологічного процесу, а досвід практичної роботи полегшує відпрацювання та закріплення практичних навичок. При цьому поєднання навчання на зварювальному обладнанні з використанням тренажерних систем дозволяє контролювати динаміку навчального процесу. Крім того, наявність запису тренувального сеансу надає можливість його подальшого аналізу і видачу рекомендацій кваліфікованим інструктором. Тому застосування тренажерів на різних етапів навчання $\epsilon$ ефективним інструментом, що дозволяє оцінити поточний прогрес зварника з метою визначення доцільності проведення атестаційних випробувань. Таким чином можливим стане забезпечення індивідуального підходу.

Для проведення досліджень було використано модернізований тренажер зварника із малоамперною дугою. Проводилася реєстрація параметрів тренувальних сеансів при виконанні імітації прямоліній- 
ного зварного шва (типове завдання) майстром виробничого навчання та групи кваліфікованих і не кваліфікованих робітників.

В ході роботи були побудовані гістограми довжини дуги на основі графіків, отриманих під час тренувальних сеансів. Проводилося обчислення основних статистичних характеристик, які дозволяють судити про характерні особливості варіаційного ряду в цілому. Найбільш часто використовуваними статистичними показниками параметрів зварювання є: середнє арифметичне, середнє квадратичне відхилення, дисперсія, коефіцієнт варіації. Побудовано графіки експериментальної функції розподілу. В даний час проводиться аналіз отриманих даних та розробляється математична модель, що дозволить відслідковувати та оцінювати індивідуальний прогрес зварника при навчанні 3 метою оптимізації навчального процесу.

\title{
Література:
}

1. Дідківський Р.М., Чвертко Є.П., Шевченко М.В., Пірумов А.С., Проценко П.П. Аналіз стану кваліфікаційних заходів з атестації зварників в Україні. Технологические системы. 2019. № 1(86). С. 19-23.

DOI https://doi.org/10.30525/978-9934-588-79-2-1.26

\section{ВЛИЯНИЕ НАПРАВЛЕНИЯ И ВЕЛИЧИНЫ ПОДАЧИ НА ДЕМПФИРУЮЩИЕ СВОЙСТВА ПРОЦЕССА ФРЕЗЕРОВАННИЯ КОНЦЕВЫМИ ФРЕЗАМИ}

\author{
Дядя С. И. \\ кандидат технических наук, доцент, \\ заведующий кафедрой технологии машиностроения \\ Национального университета «Запорожская политехника» \\ Козлова Е. Б. \\ кандидат технических наук, \\ дочент кафедры технологии машиностроения \\ Наџионального университета «Запорожская политехника» \\ Козлов М. Д. \\ магистр \\ Национального университета «Запорожская политехника», \\ г. Запорожье, Украина
}

Колебания, возникающие при концевом фрезеровании, связанные как с ударами при врезании зуба фрезы, так и с процессом резания, 